\title{
構造体のヒステリシス評価とカ学モデルの構築
}

河内 毅*1，栗山 幸久 ${ }^{* 2}$ ，鈴木 克幸*2

\section{Evaluation and modeling of structural hysteresis}

\author{
Takeshi KAWACHI $^{* 1}$, Yukihisa KURIYAMA ${ }^{* 2}$ and Katsuyuki SUZUKI ${ }^{* 2}$ \\ ${ }^{* 1}$ Nippon Steel \& Sumitomo Metal Corporation \\ 20-1 Shintomi, Futtsu-shi, Chiba 293-8511, Japan \\ ${ }^{* 2}$ Research into Artifacts, Center for Engineering, The Tokyo University \\ 5-1-5 Kashiwanoha, Kashiwa-shi, Chiba 277-8568, Japan
}

Received: 31 July 2017; Revised: 21 September 2017; Accepted: 22 October 2017

\begin{abstract}
In order to clarify the mechanism of the vehicle body hysteresis affecting "rigidity feeling", one of the driver's sensory evaluation in the driving test, the influence of friction acting on spot welding flanges on hysteresis, which is drawn by displacement - load diagram under static or relatively slow deformation of double-hat-shaped parts assembled by spot welding, is experimentally evaluated. By measuring the difference between loss energy of a specimen with strong contact on welding flanges and that of another specimen without contact, friction loss (energy dissipation generated only by friction excluding inevitable loss energy for measurement possessed by testing system itself) is calculated. The friction loss rising with increasing load amplitude and load rate confirms that friction hysteresis occurs in the structure even under the elastic deformation. In this paper, the load rate dependence and the extrapolation point to the zero load rate are evaluated as the dynamic and static characteristics of friction loss, respectively. As a result, the dynamic characteristic obtains a result proportional to the load amplitude, and the static characteristic is proportional to the square of the load amplitude. Additionally, a model with the reaction force as the sum of linear elastic resistance due to bending and shear deformation, Coulomb friction proportional to amplitude of displacement and viscous friction is proposed. Using this model, the prediction of static and dynamic characteristic of the friction loss shows good agreement with results of the experiment. Finally, the friction-induced hysteresis led from the model is quantitatively discussed.
\end{abstract}

Keywords : Vehicle body, Hysteresis, Rigidity feeling, Friction loss, Friction, Spot welding flange

\section{1. 緒言}

近年，自動車の軽量化に対する要求が㛜しさを増しており，アルミニウム等の低密度金属や CFRP に代表され る繊維強化型プラスチックを自動車の車体やシャシ部品に適用することで軽量化を図る例が見られるが，鉄鋼材料 においても，高強度・薄手材料（ハイテン材）の適用によって自動車の軽量化と衝突安全性の両立に貢献してい る.しかし, 単なる薄手ハイテン材への材料置換は, 車体剛性を低下させ，車両の運動特性（操縦安定性や乗り 心地）の低下をまねくため（椎葉他，2013，嶋中他，2009，冨岡他，2009，内山他，2015），構造や接合方法の 工夫によって車体剛性を高める取組みが多く報告されている（嶋中他，2009，冨岡他，2009）。一方，車体剛性の 高低とは無関係に，実走行試験におけるドライバによる「剛性感」や「操作と車両の動きの一体感」という官能

No.17-00334 [DOI:10.1299/transjsme.17-00334], J-STAGE Advance Publication date : 1 November, 2017

*1 正員，新日鐵住金（株）（产293-8511 千葉県富津市新富 20-1）

*2 正員, 東京大学 人工物工学研究センター（†277-8568 千葉県柏市柏の葉 5-1-5)

E-mail of corresponding author: kawachi.a5q.takeshi@jp.nssmc.com 
評価によって，車の善し悪しが決められることがある．車体のねじり剛性のヒステリシス（ねじり変形の位相の 遅れ）が大きいと, ドライバは「ハンドル操作と車両の動きの一体感がない」と感じるという報告が自動車メー カよりなされている（嶋中他，2009）。この報告においては，上記ヒステリシスの発生要因としてスポット溶接部 の塑性変形を挙げている. しかし, 実際の車両走行にいてスポット溶接の塑性変形について解析した報告例は少 なく, また，それらも未舗装路（悪路）走行における大きな荷重入力の下におけるスポット溶接部の破壊に着目し た評価に限られる（武田他，2013）。悪路に比べて入力荷重が低い一般的な舗装された路面の走行のように，車体 を構成する部品に導入されるひずみが十分に低い領域おいて，車体のヒステリシスがなぜ生じるのかという疑問 に対して明確に答える報告はない。

一般的な機械構造物に対象を広げると，ボルト締結部やスポット溶接された平板接合構造の摩擦面における固 着-滑りが生み出す動的なヒステリシス現象を振動隇衰によって評価する報告がある (Abad et al., 2012, Abbadi et al., 2004, 平居他, 2014, 品川, 社本, 2012) . 平居らは, 部分的な重なりを持つ二枚の金属板を金属治具とと もにボルトで締結した試験体を対象に，接触を考慮しない有限要素モデルを用いて固有モードを計算し，得られ たモード変位を強制変位とした有限要素モデルによる静的接触解析を実施し，二枚の金属板間の接触部に生じる 摩擦力と相対変位から, 摩擦による振動減衰を推定する手法を提案している（平居他, 2014）。さらに, その手 法を用い，ボルト締結個所を変更することで金属板間の接触分布を変化させることで咸衰が増減し，実測と整合 する面圧はモードによって変化することを報告している．また，一点のスポット溶接において，ナゲット周辺に 形成されるコロナボンド間における接触圧力を考虑し, 試験体の $160 \mathrm{~Hz}$ 以上の固有振動モードにおいて生じるコ ロナボンドにおける接触摩擦による減衰を, 実験および数值解析によって定量的に評価する報告がなされている （Abbadi et al., 2004）。ここで報告される数值解析結果によると，溶接時に生じるコロナボンドの接触圧力を初期 与圧とし, 摩擦面における Coulomb 摩擦を考慮すると, 与圧がない場合に比べて試験体の減衰が高くなり, 実測 值に近づく結果を示す。

自動車車体は多くの部品がスポット溶接によって組み上げられているが，前述の接触による減衰効果の報告か ら, 準静的な繰り返し荷重の付与において, 摩擦を起因とするヒステリシス発生が推測できる. しかし, 前述の 平居ら，および，Abbadi らの報告を含め，従来の報告は，金属板の固有振動モードにおける固着-滑り現象を減 衰によって評価したものであり, 自動車車体のように薄鋼板を成形しスポット溶接で組み上げられる構造体を対象 に, 静的, もしくは, 低速で部品同士が相対運動する準静的な荷重条件における接触を起因とするヒステリシス に関する研究報告はない, さらに, スポット溶接が施工される二つ, または, それ以上の部品の接合面は設計上 では互いに平行であっても, 実際にプレス成形される部品はスプリングバックによって設計図面形状からずれが 生じるため, 成形直後に互いに非平行な接合面をスポット溶接ガンで強制的に接触させながら溶接することにな る（吉田他, 2012）。したがって, 実際の自動車車体では, 接合面の一部において, 前述の Abbadi らの報告で言 及されているコロナボンド部分よりも広い範囲において部品同士の接触が生じる. また，その接触領域は，コロ ナボンドよりも溶融ナゲットから離れているため溶融ナゲットの拘束を受けにくく, 接触面における相対すべり運 動がより生じやすいことから, 実際の自動車車体を構成する部品では, Abbadi らが扱った試験体よりも大きな摩 擦ヒステリシスを発生させる可能性がある. 自動車の操縦安定性に強く関わる周波数域は数 $\mathrm{Hz}$ 以下の低周波域で あること（Irwin, 1981，中谷，1984，武井他，2001）も踏まえ，自動車車体における静的，または，準静的なヒス テリシスの原因を解明し, 低減する設計技術を確立することは, 車体の軽量化と「剛性感」の向上に寄与するも のと考えられる.

本研究において, 薄鋼板を成形した二つの部品を接合面において強い接触が生じるようにスポット溶接した試 験体の端面にせん断荷重を低速で与える実験を行い, 得られる変位-荷重ヒステリシスループを積分して得られる 損失エネルギについて, 接触部位を持つ試験体と持たない試験体を比較することで接合面における摩擦を起因と する損失エネルギ（以下，摩擦損失エネルギ）を抽出する手法を提案する. 実験結果の荷重速度に対する依存性 を調ベ, 摩擦損失エネルギの静的および動的特性を議論する.さらに, 摩擦を考慮した単純な力学モデルから導 出される摩擦損失エネルギが実験結果と良い一致を示すことを報告する. 


\section{2. 試 験 方 法}

\section{$2 \cdot 1$ 試験体形状と試験機構成}

試験体は, 図 1 に示すように, 板厚 $t_{\mathrm{S}}=1.4 \mathrm{~mm}$, 長さ $L=293 \mathrm{~mm}$ の引張強度 $440 \mathrm{MPa}$ 級鋼板を曲げ加工によっ て成形した二つのハット型部品を溶接フランジ（以下，フランジ）において片側 8 か所を溶融ナゲット径 $6 \mathrm{~mm}$ (狙い),$p_{\mathrm{SW}}=35 \mathrm{~mm}$ ピッチでスポット溶接し，その両端に $B_{\mathrm{P}} \times B_{\mathrm{P}} \times t_{\mathrm{P}}=200 \mathrm{~mm} \times 200 \mathrm{~mm} \times 15 \mathrm{~mm}$ の寸法を 持つ厚鋼板をアーク溶接によって接合する，ダブルハット試験体（specimen）である.上部の厚鋼板を連結端板 (connecting plate)，下部を固定端板（base plate）と呼ぶ. 両端板溶接後に上下端面に機械加工による切削を施し， 端板と連結治具およびベース治具との接合面における平滑および二つの端面の平行を確保する. 図 2 に示すよう に試験体の断面形状は二種類あり，フランジをスポット溶接する前にフランジ同士が平行になるよう成形した A, および，成形時のスプリングバックを再現したフランジ面が R 止まりからエッジに向かって隙間が広がるように 成形した B である. 断面 B を持つダブルハット試験体（以下，試験体 B）は，溶接ガンの圧下力でフランジを押 さえつけながら溶接するため， $\mathrm{R}$ 止まり付近において互いに強く接触することになる．実際に溶接組み立てされた 試験体 B において, 板エッジから R 止まりに向かいフランジ間隔は狭まり，エッジ側から挿入する $10 \mu \mathrm{m}$ 厚の隙 間ゲージがフランジ中央部までしか入らないことが確認されることから， R 止まり近傍においてフランジ同士が接 触しているものと考えられる。一方，断面 A を持つダブルハット試験体（以下，試験体 A）では，フランジをス ポット溶接した際, 熱の影響によりスポット溶接点以外の部位が互いに遠ざかる変形が発生する（須藤他，1982）. 実際にスポット溶接された試験体 $\mathrm{A}$ において，スポット溶接点以外のフランジ間に $10 \mu \mathrm{m}$ 厚の隙間ゲージが挿入 可能なことが確認され，溶融ナゲット周辺以外のフランジのほぼ全域において接触が発生しない. フランジのほ ぼ全域で接触摩擦がない試験体 A と強い接触摩擦を生じる試験体 B を比較することで, 鋼板の接触摩擦によって 生じるヒステリシスについて，定量的な評価を試みる.
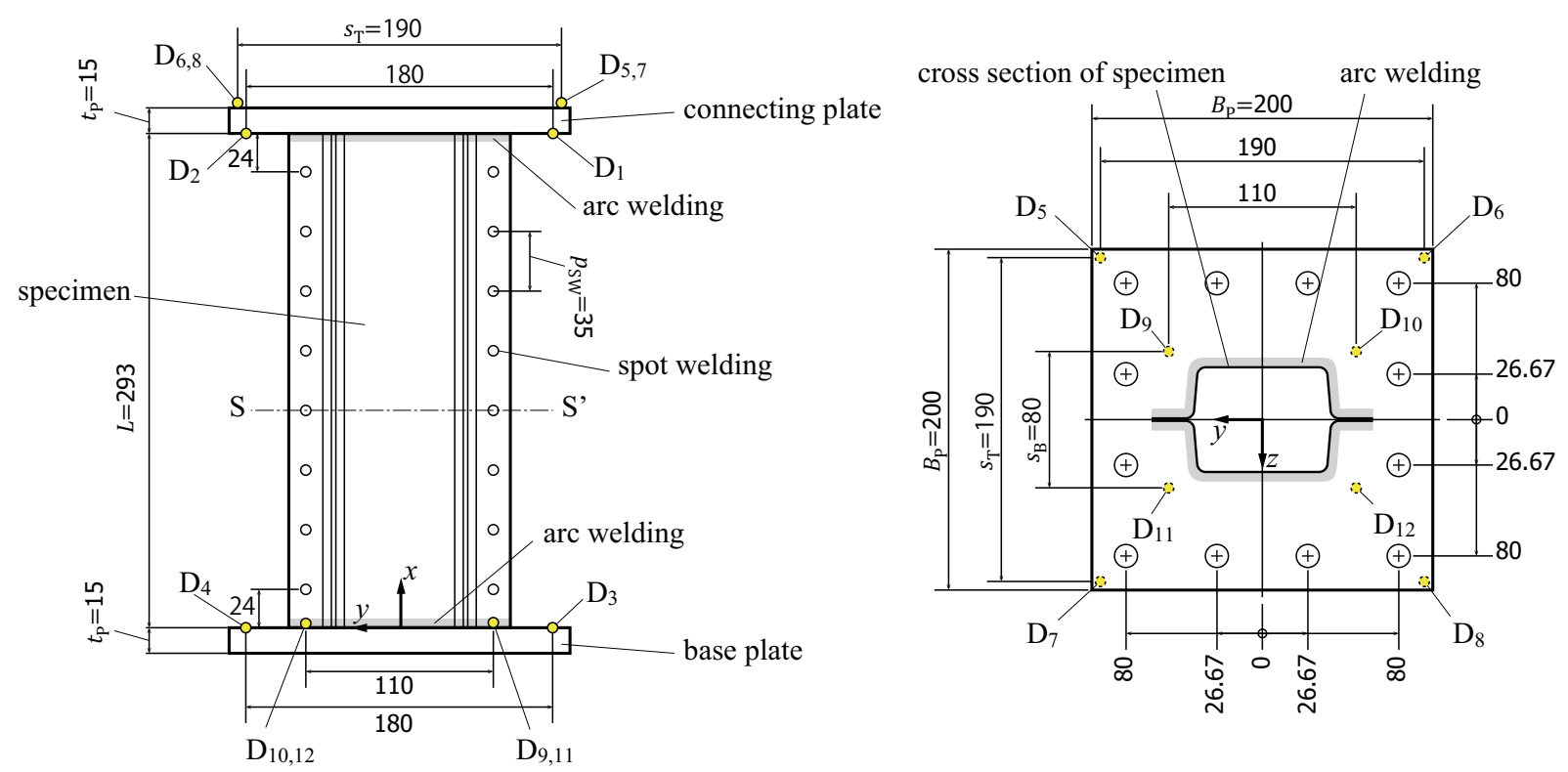

Fig. 1 the schematic side-view of the specimen (left) and top-view of connection and base plate (right) in units of millimeter. Circles noted by characters $\mathrm{D}_{i}(i=1,2, \cdots, 12)$ show the measurement points of displacement.

図 3 に示すように, 試験体は, 試験体軸心が上下方向（ $x$ 軸, 図 3 右図の上向きを正とする $)$, 水平方向（ $z$ 軸, 図 3 右図の左向きを正とする）に配向した荷重軸線（load axis）にフランジ面鉛直方向が一致するように配置し， 試験体の固定端版を $y z$ 面に水平な定盤に治具（base jigs）を介して固定し，連結端盤に球面ジョイント（spherical joint）を介してアクチュエータに接合される連結治具（connecting jig）をボルトで固定する. 球面ジョイント中心 は無負荷状態において試験体断面の図心軸上に配置され, 試験体と端板の溶接線からの距離は $l=83 \mathrm{~mm}$ である.

アクチュエータは, パルス幅制御ステッピングモータ（stepping motor，オリエンタルモーター製， PS ギヤード 


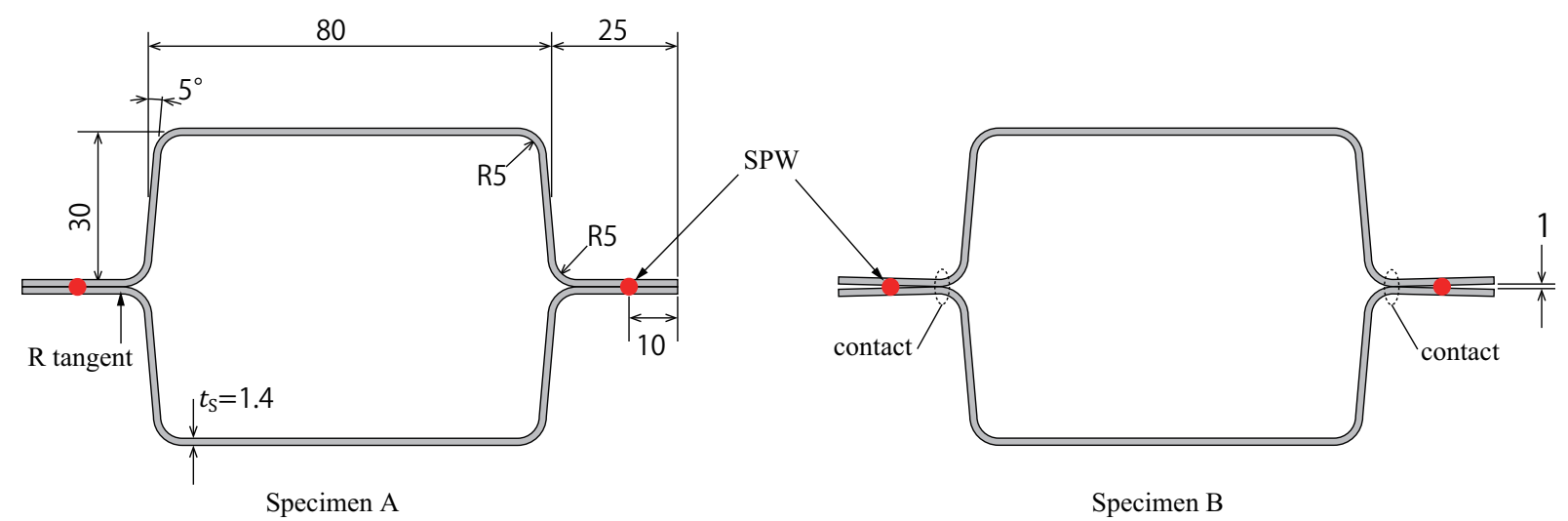

Fig. 2 the shapes of cross section of specimens at the section of S-S' in Fig. 1. The dimensions are the values before spot welding in units of millimeter. Before spot welding, specimen B has a clearance between its two flanges at the location of spot welding. After spot welding, they have contact area around R tangent of flanges.
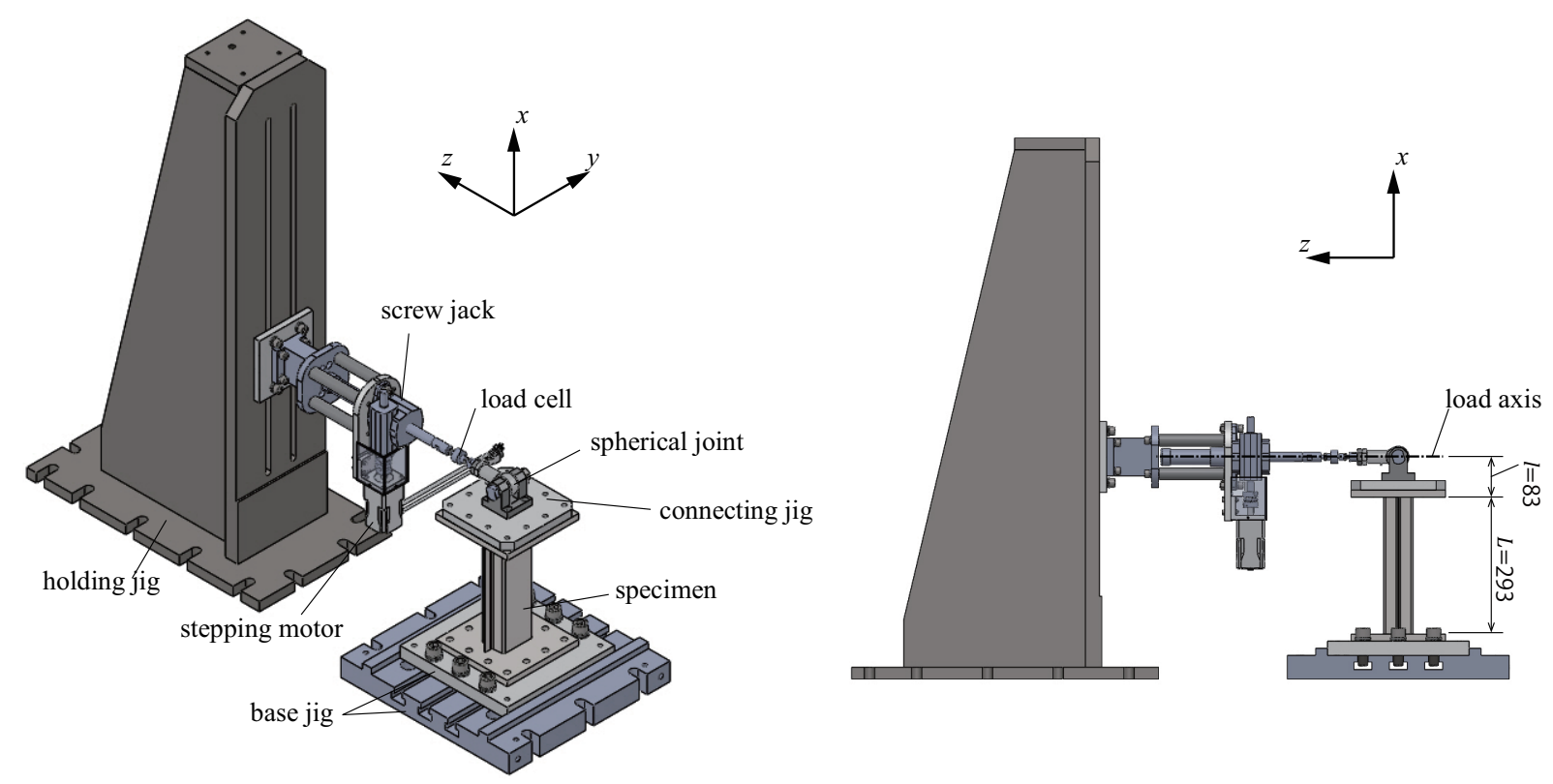

Fig. 3 the structure of measurement system (left: iso-view, right: side-view). The load axis and the centroid axis of specimen are parallel to $z$ - and $x$-axis, respectively. The normal vector of flange surface of double-hat specimen is parallel to $z$-axis.

タイプ AZM66AC-PS5）によって位置を制御され，一軸上を $z$ 軸方向に並進移動するスクリュージャッキ（screw jack，日本ギア工業製，J0G LUK 0100 B SN）を用いる．以上で組み上げられるアクチュエータの能力を表 1 にま とめる．スクリュージャッキのハウジングは，定盤に固定された鉛直反力面を持つ反力治具（holding jig）に固定 され, 定盤に対して全自由度を拘束される. スクリュージャッキの可動軸先端と球面ジョイントの間には引張圧縮 両用ロードセル（load cell, 東京測器製, TCLA-5KNA）を設置し, 軸力を計測する.

Table 1 the abilities of actuator.

\begin{tabular}{c|c|c|c}
\hline \hline Maximum force & Maximum stroke & Maximum Speed & Resolution \\
\hline $10[\mathrm{kN}]$ & $\pm 100[\mathrm{~mm}]$ & $1.7[\mathrm{~mm} / \mathrm{sec}]$ & $0.033[\mu \mathrm{m}]$ \\
\hline
\end{tabular}




\section{2 荷重軸線上変位の定義}

アクチュエータの推力によって試験体はせん断力および曲げモーメントを受け，せん断および曲げ変形する. 試験体のたわみ量を評価するため, 連結端板および固定端版の $z$ 方向変位を 4 つのレーザ変位計（Keyence 製, LK-H057 および LK-H027）を用い測定する，さらに，試験体上端および試験体下端の断面のたわみ角を評価する ため, 連結端板および固定端板上面の $x$ 方向変位をそれぞれ 4 つのレーザ変位計（Keyence 製， LK-H057 および LK-H027）を用い測定する．試験体は薄板で構成されており，局所的な変形が生じやすいことが推定されるため （古巣他，2015），また，試験体端板と接続治具間において微小な滑りが生じることも想定されるため，すべての 変位測定点は比較的剛で試験体と溶接によって直接接合される両端板の表面に設定される.さらに，変位測定点 には表面が滑らかなセラミックス製のターゲットを貼付し，移動に伴う粗度変化の影響を最小限にとどめる．変 位計による端板の変位測定結果を用い, 荷重線と試験体図心軸との交点, つまり, 球面ジョイントの中心の変位を 算出する.まず，図 1 に示すように，連結端板下面高さにおいて試験体図心軸に対し対称に互いに $180 \mathrm{~mm}$ 離れた 2 点 $\left(\mathrm{D}_{1}, \mathrm{D}_{2}\right)$ における荷重軸方向（ $z$ 軸方向）変位（点 $\mathrm{D}_{i}$ での変位量を $d_{i}$ とする）の平均 $d_{\mathrm{T}}$ と固定端板上面に おいて試験体図心軸に対し対称に互いに $180 \mathrm{~mm}$ 離れた 2 点 $\left(\mathrm{D}_{3}, \mathrm{D}_{4}\right)$ における $z$ 軸方向変位の平均 $d_{\mathrm{B}}$ の差,

$$
\begin{aligned}
d_{\mathrm{T} 0} & =d_{\mathrm{T}}-d_{\mathrm{B}} \\
& =\frac{d_{1}+d_{2}}{2}-\frac{d_{3}+d_{4}}{2}
\end{aligned}
$$

を試験体上端の断面のたわみ量と定義する．また，連結端板の上面内に描かれる一辺 $s_{\mathrm{T}}=190 \mathrm{~mm}$ の正方形の 4 頂 点 $\left(\mathrm{D}_{5}, \mathrm{D}_{6}, \mathrm{D}_{7}, \mathrm{D}_{8}\right)$ における $x$ 軸方向変位から計算される連結端板回転角 $\theta_{\mathrm{T}}$ と固定端板の上面内に描かれる $z$ 軸 方向長さ $s_{\mathrm{B}}=80 \mathrm{~mm}, y$ 軸方向長さ $100 \mathrm{~mm}$ の長方形の 4 頂点 $\left(\mathrm{D}_{9}, \mathrm{D}_{10}, \mathrm{D}_{11}, \mathrm{D}_{12}\right)$ における $x$ 軸方向変位から計算 される固定端板回転角 $\theta_{\mathrm{B}}$ の差,

$$
\begin{aligned}
\theta_{\mathrm{T} 0} & =\theta_{\mathrm{T}}-\theta_{\mathrm{B}} \\
& =\arctan \frac{-d_{5}-d_{6}+d_{7}+d_{8}}{2 s_{\mathrm{T}}}-\arctan \frac{-d_{9}-d_{10}+d_{11}+d_{12}}{2 s_{\mathrm{B}}}
\end{aligned}
$$

を試験体上端断面のたわみ角として定義する，さらに，端板や連結治具を剛体とみなすと，(1）および式（2）を 用いて, 荷重線と試験体図心軸の交点, つまり, 球面ジョイントの中心において試験体の曲げおよびせん断変形に よって生じる荷重軸線上変位を,

$$
\delta=d_{\mathrm{T} 0}+l \theta_{\mathrm{T} 0}
$$

\section{と定義する.}

\section{$2 \cdot 3$ 摩擦損失エネルギ}

式（3）で定義される変位 $\delta$ とロードセルで計測される荷重 $F$ は, 図 4 に示すようにヒステリシスカーブを描 く．本報告では，損失エネルギ $E_{\mathrm{S}}$ をヒステリシスカーブによって囲まれる面積として算出する．しかし，この損 失エネルギには測定装置が固有に持つヒステリシス，たとえば，球面ジョイントにおける摩擦や固定端における 微小な変位による摩擦損失, また, わずかであると予想される試験体を構成する材料の弾性ヒステリシス等を含

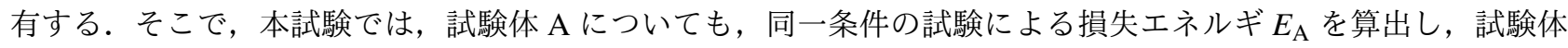
$\mathrm{B}$ を用いた試験における損失エネルギ $E_{\mathrm{B}}$ との差,

$$
E_{\mathrm{Bf}} \equiv E_{\mathrm{B}}-E_{\mathrm{A}}
$$

をダブルハット試験体 B の摩擦損失エネルギとして定義し，この值を用いて摩擦ヒステリシスを議論する．なお， 
試験体 B のフランジ面内におけるスポット溶接の溶融ナゲットから数 $\mathrm{mm}$ 離れた領域にある接触部に比ベ，溶融 ナゲットに隣接するコロナボンドにおいては, フランジの相対運動が強く拘束されるため, 今回の試験では, コ ロナボンド部における摩擦の影響は無視する.

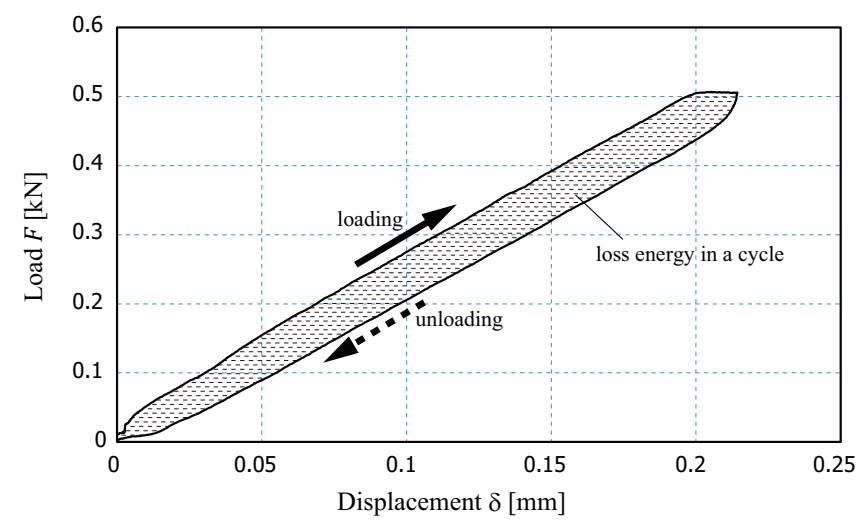

Fig. 4 an example of the load displacement diagram. The horizontal axis is displacement calculated by equation (3) in units of millimeter, and the vertical axis is the axial load in units of kilonewton. The area surrounded by the load - displacement diagram means the loss energy in a test cycle.

\section{$2 \cdot 4$ 試験条件}

スクリュージャッキの並進運動は荷重を増減させ，その並進位置はステッピングモータの回転角で制御される. 本試験では, 目標とする最小荷重が得られるようにステッピングモータを制御する. その点を試験開始点として目 的とする最大荷重に至るまでステッピングモータの回転角を時間とともにほぼ直線的に変化させ, 最大荷重に達 したところで 2 秒間保持する．続いて，目標とする最小荷重に至るまで時間とともにほぼ直線的に変化させ，最 小荷重に達したところで 2 秒間保持する. これを 1 サイクルとして, 複数 $(4 \sim 6)$ サイクルを連続して繰り返す. 最大荷重, および, 荷重速度を, 表 2 に示す 6 , および, 9 水準で実施する. なお, 荷重ゼロ点付近におけるアク チュエータの遊びの影響を除外するため，常に正の荷重がかかるよう，最小荷重は， $0.01 \mathrm{kN}$ とする.

Table 2 the test conditions for the maximum load and load rate.

\begin{tabular}{|c|c|c|c|c|c|c|c|c|c|c|}
\hline Maximum load & 0.25 & 0.5 & 0.75 & 1.0 & 1.25 & 1.5 & & & & {$[\mathrm{kN}]$} \\
\hline Load rate & 0.1 , & 0.2 & 0.4 & 0.8 & 1.2 & 1.6 & 2.0 & 2.4 & 3.2 & {$[\mathrm{kN} / \mathrm{sec}]$} \\
\hline
\end{tabular}

\section{3. 試 験 結 果}

\section{$3 \cdot 1$ 変位一荷重線図}

図 5 に試験体 $\mathrm{A}$ の 3 つの速度条件, および，3つの最大荷重条件での試験結果, 変位-荷重線図を比較する. 速 度の上昇に伴い, 載荷と除荷の過程において通過する経路が離れる. 一方, 最大荷重は載荷と除荷の過程におい て通過する経路の距離にほとんど影響を与えず，荷重および変位範囲が拡大する.

荷重の変動幅（最大荷重と最小荷重の差）と式（3）で定義される変位の変動幅（最大変位と最小変位の差）の 比を等価剛性として定義し, 試験体 A について全試験結果の平均をとると, $2.31 \mathrm{kN} / \mathrm{mm}$ であ. 図 1 および 2 に 示す試験体 A の設計寸法から数值解析（汎用有限要素法ソフト MSC Nastran を使用した線形弾性解析）によって 計算される剛性值, $2.47 \mathrm{kN} / \mathrm{mm}$ とほぼ一致する.これは, 今回の試験系の構成部位のうち, 試験体がもっとも剛 性が低く，スクリュージャッキやロードセル等の他の部位は試験体よりも十分剛であることを意味する. 


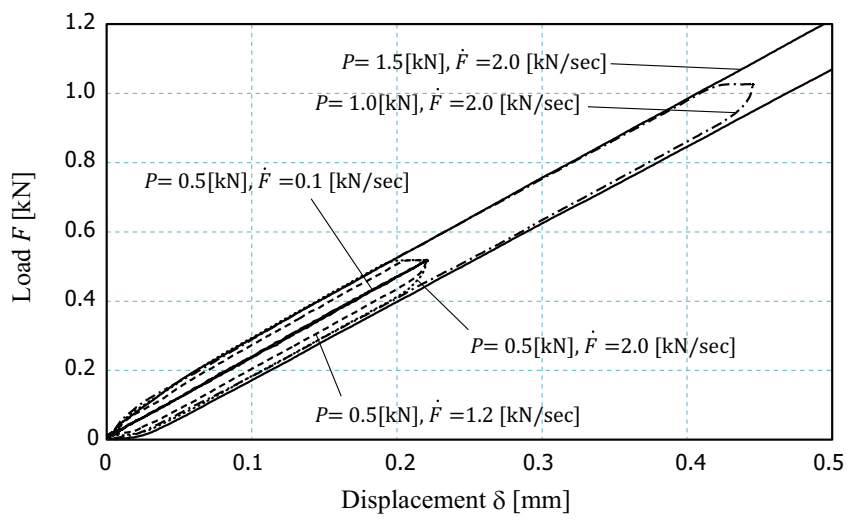

Fig. 5 the result of the test: the displacement - load diagram of specimen A. The horizontal axis is displacement calculated by equation (3) in units of millimeter, and the vertical axis is the axial load in units of kilonewton. Each line is the result of five testing conditions showed in table 2.

\section{$3 \cdot 2$ 摩擦損失エネルギ測定結果}

最大荷重および荷重速度がヒステリシスループの面積から計算される損失エネルギに及ぼす影響を図 6 に整理 する. 最大荷重および荷重速度の増加に伴い, 両試験体の損失エネルギ $E_{\mathrm{A}}$ および $E_{\mathrm{B}}$ はほぼ線型に増加すること がわかる.また, 試験体 A に比べて B の方が, 損失エネルギが大きい. 式 (4) で定義される摩擦損失エネルギ の計測結果を最大荷重ごとに整理し，図 7 に示す。ややばらつきがあるものの，破線で示す近似のように，最大 荷重および荷重速度の上昇に伴い摩擦損失エネルギがほぼ線型に増加する。また，荷重速度ゼロの外挿点におい て，摩擦損失エネルギは正值を持つ。
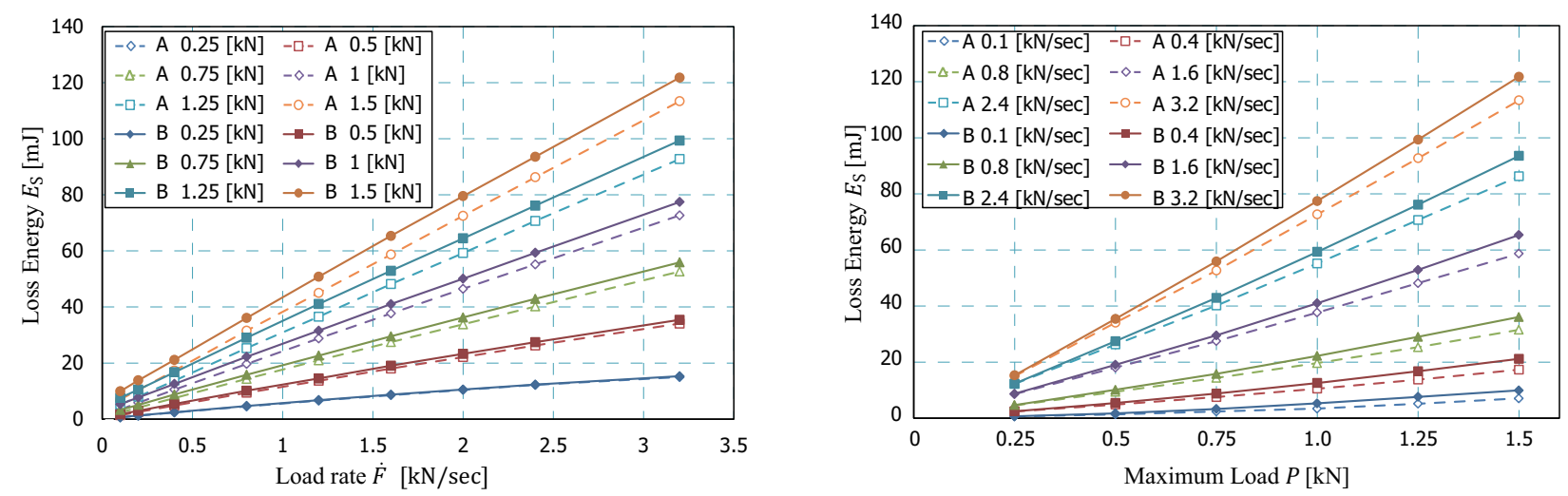

Fig. 6 the loss energy of tests for specimen A and B. Left figure: the horizontal axis is the deflection by load rate $\dot{F}$ in units of $[\mathrm{kN} / \mathrm{sec}]$ and the vertical axis is the mean loss energy of specimen, the area surrounded by the load $F$ and displacement $\delta$ diagram in a test cycle in units of millijoule. All plots are distinguished by maximum load. Right figure: the horizontal axis is the deflection by maximum load $P$ in units of kilonewton and the vertical axis is the mean loss energy of specimen in units of millijoule. All plots are distinguished by load rate.

\section{$3 \cdot 3$ 摩擦損失エネルギの動的および静的特性}

前節で示したように，試験体 B の摩擦損失エネルギは荷重速度に対して線形的に変化する．図 7 に示すグラフ における, 各近似直線の傾きを摩擦損失エネルギの動的特性として, 荷重速度ゼロへの外挿点おける摩擦損失エ ネルギ（近似直線の縦軸切片）を静的特性とし, 図 8 にそれらの評価結果を示す. 摩擦損失エネルギの動的特性 は, 試験の最大荷重にほぼ比例することがわかる。一方, 静的特性は, 試験の最大荷重の平方にほぼ比例する結 果を得る。 


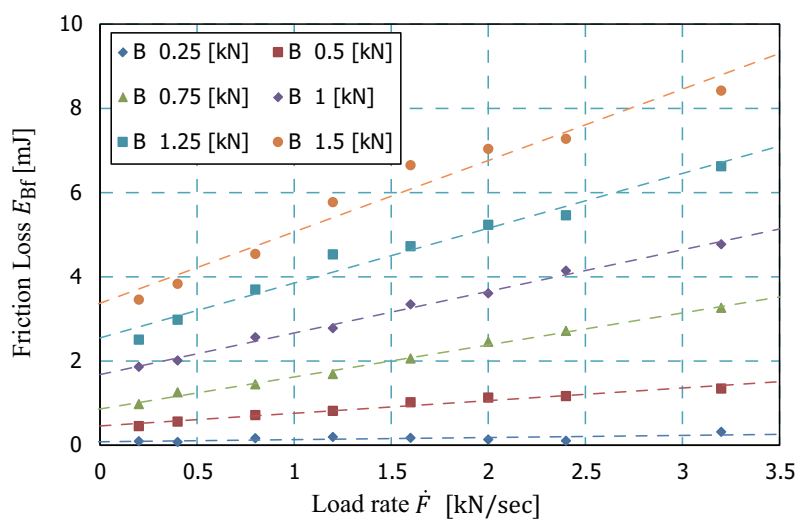

Fig. 7 the friction loss of specimen B. The horizontal axis is the rate of load $\dot{F}$ in units of $[\mathrm{kN} / \mathrm{sec}]$ and the vertical axis is the friction loss $E_{\mathrm{Bf}}$ in units of millijoule. All plots are distinguished by maximum load and the dash-lines are straight approximate by load rate on each maximum load level.
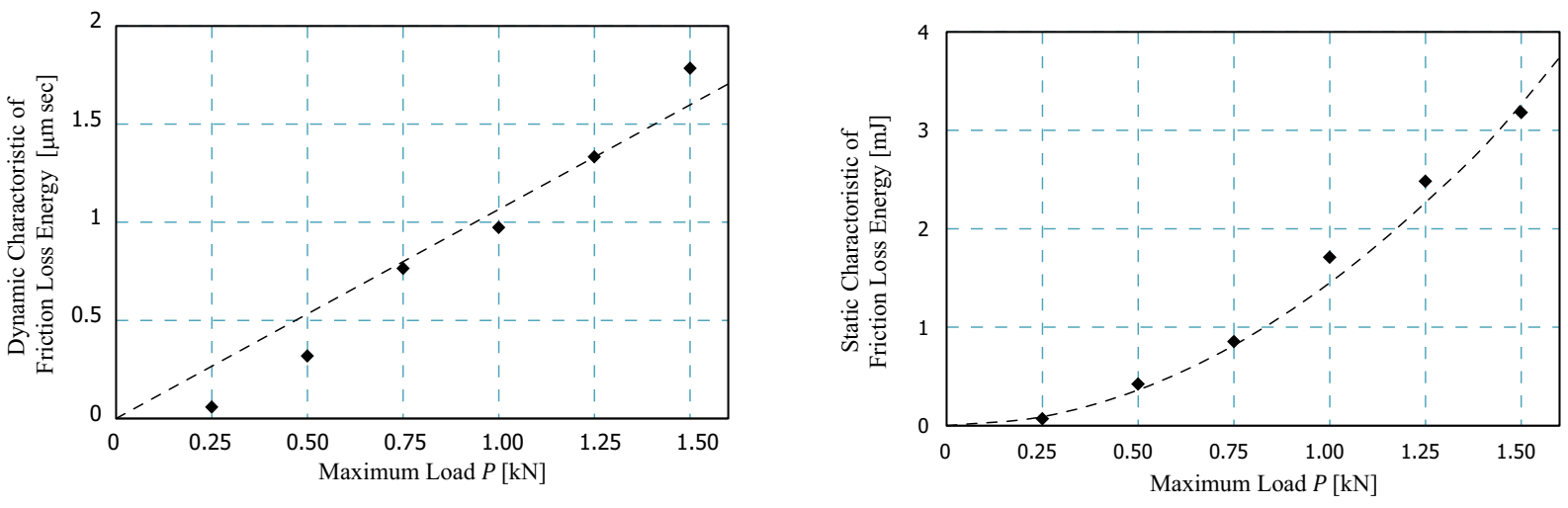

Fig. 8 the dynamic characteristic (left) and the static characteristic of friction loss (right). Left figure: the horizontal axis is the maximum load in units of kilonewton, and the vertical axis is the dynamic characteristic of friction loss determined as gradient of friction loss to load rate on each maximum load in figure 7 in units of $[\mu \mathrm{m} \mathrm{sec}]$. The dash-line means straight approximate passing through the origin. Right figure: The horizontal axis is the maximum load in units of kilonewton, and the vertical axis is the static characteristic of friction loss determined as friction loss-axis intercept on each maximum load in figure 7 in units of millijoule. The dash-line means second-order approximate passing through the origin in gradient zero.

\section{4. 考察}

\section{$4 \cdot 1$ 摩擦損失エネルギの力学モデル構築}

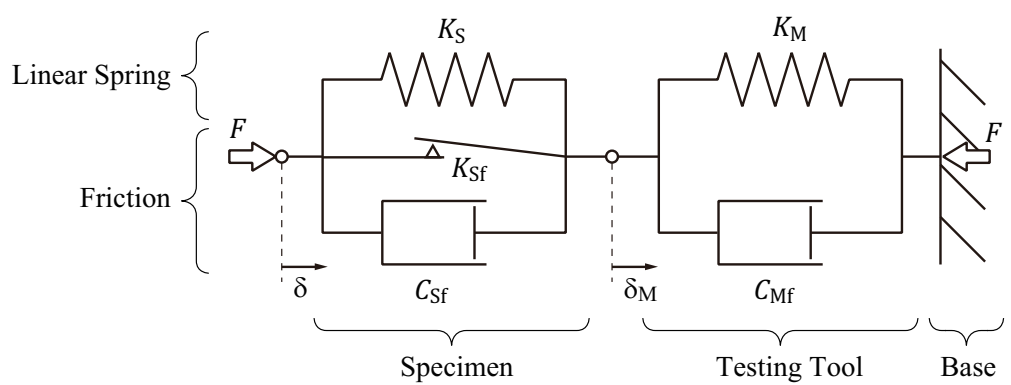

Fig. 9 the simple model of the measurement system composed of two spring models. One is the model for specimen with a linear spring, a slider for Coulomb friction and a dashpot for viscous friction and the other is the model for testing tools with a linear spring and dashpot. 
9 に示すように，アクチュエータによる荷重 $F$ が，直列につながる試験体系（Specimen）と試験機系（Testing Tool） を介して固定端（Base）における反力と釣り合うモデルを考える．試験体系および試験機系ともに弾性変形によ る抵抗と摩擦による抵抗の和が軸力と釣り合う。試験体系における摩擦は，フランジにおける Coulomb 摩擦と粘 性摩擦の効果を, 試験機系における摩擦は球面ジョイント等における粘性摩擦の効果のみを考慮する. さらに, 試 験体系における Coulomb 摩擦は変位の変化方向と逆向きに作用し, 荷重によって試験体の変形が増すに従い, フ ランジ接触面における接触圧が高まる，または，接触面積が増加することによって摩擦力が高まることでフランジ 面垂直抗力が増加すると考え, 垂直抗力と摩擦係数の積である Coulomb 摩擦の効果は試験体系変位の絶対值 $\left|\delta_{\mathrm{S}}\right|$ に比例する大きさを持つとする. 試験機系の変位を $\delta_{\mathrm{M}}$, 全体の変位（荷重力線上の変位）を $\delta=\delta_{\mathrm{S}}+\delta_{\mathrm{M}}$ とする. 試験体系の線型弾性係数（試験体の剛性）, 粘性係数, Coulomb 摩擦の変位の絶対值に対する比例係数（以下, 摩 擦剛性), 試験機系の線型弾性係数（試験機の剛性），および, 粘性係数をそれぞれ， $K_{\mathrm{Se}}, C_{\mathrm{Sf}}, K_{\mathrm{Sf}}, K_{\mathrm{Me}}$, およ び， $C_{\mathrm{Mf}}$ とする. 試験体系に現れる添え字 S は, 試験体の名前, A および B を示す. 以上の表記の下で, 力の釣 り合いの式は,

$$
K_{\mathrm{Se}} \delta_{\mathrm{S}}+\operatorname{sgn}\left(\dot{\delta}_{\mathrm{S}}\right) K_{\mathrm{Sf}}\left|\delta_{\mathrm{S}}\right|+C_{\mathrm{Sf}} \dot{\delta}_{\mathrm{S}}=K_{\mathrm{Me}} \delta_{\mathrm{M}}+C_{\mathrm{Mf}} \dot{\delta}_{\mathrm{M}}=F
$$

と表現される.ここで, (·) は時間による一階微分, $\operatorname{sgn}($ ) は ( ) 内の符号を持つ大きさが 1 の值とする.この力の 釣り合いにおいて, 荷重ゼロから最大荷重 $P$ まで一定の速さ $\dot{\delta}=v(>0)$ で載荷し, 最大荷重 $P$ から荷重ゼロまで 一定の速さ $\dot{\delta}=-v(<0)$ で除荷することを考える.なお， $2 \cdot 4$ 節において示す試験条件の最小荷重をほぼゼロとみ なして検討を進める. 荷重反転における加減速時の変位は無視すると, 試験体系および試験機系が 1 サイクルで 失う損失エネルギ $E_{\mathrm{S}}$ は,

$$
\begin{aligned}
E_{\mathrm{S}} & =\oint F \mathrm{~d} \delta \\
& \simeq \int_{0}^{\delta_{\max }} K_{\mathrm{S} 1} \delta+C_{\mathrm{S} 1} v \mathrm{~d} \delta+\int_{\delta_{\max }}^{0} K_{\mathrm{S} 2} \delta-C_{\mathrm{S} 2} v \mathrm{~d} \delta \\
& =\left(K_{\mathrm{S} 1}-K_{\mathrm{S} 2}\right) \delta_{\max }^{2}+\left(C_{\mathrm{S} 1}+C_{\mathrm{S} 2}\right) v \delta_{\max }
\end{aligned}
$$

となる.ここで, $\delta_{\max }>0$ は, 荷重力線上の最大変位であり, 上式中の試験体系と試験機系を合わせた全体系の剛 性 $K_{\mathrm{S} 1}, K_{\mathrm{S} 2}, お よ ひ ゙ ，$ 全体系の粘性係数 $C_{\mathrm{S} 1}, C_{\mathrm{S} 2}$ は，

$$
\left.\begin{array}{ll}
K_{\mathrm{S} 1} \equiv \frac{\left(K_{\mathrm{Se}}+K_{\mathrm{Sf}}\right) K_{\mathrm{Me}}}{K_{\mathrm{Se}}+K_{\mathrm{Sf}}+K_{\mathrm{Me}}} & K_{\mathrm{S} 2} \equiv \frac{\left(K_{\mathrm{Se}}-K_{\mathrm{Sf}}\right) K_{\mathrm{Me}}}{K_{\mathrm{Se}}-K_{\mathrm{Sf}}+K_{\mathrm{Me}}} \\
C_{\mathrm{S} 1} \equiv \frac{\left(K_{\mathrm{Se}}+K_{\mathrm{Sf}}\right)^{2} C_{\mathrm{Mf}}+K_{\mathrm{Me}}^{2} C_{\mathrm{Sf}}}{\left(K_{\mathrm{Se}}+K_{\mathrm{Sf}}+K_{\mathrm{Me}}\right)^{2}}
\end{array}\right\}\left(\begin{array}{ll}
\dot{\delta}=v \geq 0), & C_{\mathrm{S} 2} \equiv \frac{\left(K_{\mathrm{Se}}-K_{\mathrm{Sf}}\right)^{2} C_{\mathrm{Mf}}+K_{\mathrm{Me}}^{2} C_{\mathrm{Sf}}}{\left(K_{\mathrm{Se}}-K_{\mathrm{Sf}}+K_{\mathrm{Me}}\right)^{2}}
\end{array}\right\}(\dot{\delta}=-v<0)
$$

と定義される．また，この全体系の剛性 $K_{\mathrm{S} 1}, K_{\mathrm{S} 2}$ を用いて，荷重力線上の最大たわみ量 $\delta_{\max }$ は,

$$
\delta_{\max }=\frac{2 P}{K_{\mathrm{S} 1}+K_{\mathrm{S} 2}}
$$

と得られる。ここで, 線形弾性剛性は摩擦剛性に比べて十分大きい, つまり, $K_{\mathrm{Se}}, K_{\mathrm{Me}} \gg K_{\mathrm{Sf}}$ とすると（このこと については，後に確認する），

$$
E_{\mathrm{S}} \simeq \frac{K_{\mathrm{Sf}}}{K_{\mathrm{Se}}^{2}} P^{2}+2 \frac{C_{\mathrm{Mf}} K_{\mathrm{Se}} / K_{\mathrm{Me}}+C_{\mathrm{Sf}} K_{\mathrm{Me}} / K_{\mathrm{Se}}}{K_{\mathrm{Me}}+K_{\mathrm{Se}}} P v
$$

と表せる. さらに，全体系の剛性 $K_{\mathrm{S}}$ を $K_{\mathrm{S} 1}$ と $K_{\mathrm{S} 2}$ の平均值として与え， $3 \cdot 1$ 節で述べたように, 今回の試験では, 
試験体の剛性に比べて他の部位は十分に剛であるので， $K_{\mathrm{Me}} \gg K_{\mathrm{Se}}$ とみなせることから，

$$
\begin{aligned}
K_{\mathrm{S}} & =\frac{K_{\mathrm{S} 1}+K_{\mathrm{S} 2}}{2} \\
& \simeq \frac{K_{\mathrm{Me}} K_{\mathrm{Se}}}{K_{\mathrm{Me}}+K_{\mathrm{Se}}} \\
& \simeq K_{\mathrm{Se}}
\end{aligned}
$$

であり, 荷重速度 $\dot{F}$ は, 変位速度 $v$ と全体系剛性 $K_{\mathrm{S}}$ の積であるので, 試験体の損失エネルギ式（9）は,

$$
E_{\mathrm{S}} \simeq \frac{K_{\mathrm{Sf}}}{K_{\mathrm{Se}}^{2}} P^{2}+2\left(\frac{C_{\mathrm{Sf}}}{K_{\mathrm{Se}}^{2}}+\frac{C_{\mathrm{Mf}}}{K_{\mathrm{Me}}^{2}}\right) P \dot{F}
$$

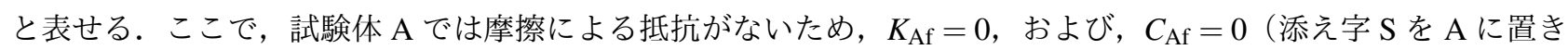
換えて表記）であることに注意すると, 試験体 $\mathrm{B}$ と $\mathrm{A}$ の損失エネルギ差である摩擦損失エネルギ $E_{\mathrm{Bf}}=E_{\mathrm{B}}-E_{\mathrm{A}}$ は, 試験体 A と B において最大荷重 $P$ と荷重速度 $F$ が同じであれば,

$$
E_{\mathrm{Bf}} \simeq \frac{K_{\mathrm{Bf}}}{K_{\mathrm{Be}}^{2}} P^{2}+2 \frac{C_{\mathrm{Bf}}}{K_{\mathrm{Be}}^{2}} P \dot{F}
$$

と, 摩擦損失エネルギを試験体の剛性と摩擦抵抗の係数のみで表現できる. 式（12）の第二項は, 荷重速度に比 例し, その比例係数 $2 C_{\mathrm{Bf}} P / K_{\mathrm{Be}}^{2}$ が, $3 \cdot 2$ 節に示す摩擦損失エネルギの動的特性（荷重速度依存性）に相当すると考 えられる. $3 \cdot 2$ 節に示す今回の試験結果から得られる摩擦損失エネルギの動的特性は最大荷重にほぼ比例しており, 上記摩擦モデルによって得られる結果と矛盾しない．また，第一項は， 3.2 節に示す摩擦損失エネルギの静的特性 に相当し，荷重速度に依存せず，最大荷重の平方に比例していることから，こちらも今回の試験結果と矛盾しな い. したがって, 式 $(12)$ 第二項の係数 $2 C_{\mathrm{Bf}} / K_{\mathrm{Be}}^{2}$, および, 第一項の係数 $K_{\mathrm{Bf}} / K_{\mathrm{Be}}^{2}$ は, それぞれ, 図 8 左図中の 近似線の傾き，および，図 8 右図中の近似線の 2 次の微係数として定めることができる．また，試験体 $\mathrm{B}$ の線形 弾性剛性 $K_{\mathrm{Be}} \simeq K_{\mathrm{B}}$ は，荷重の変動幅（最大荷重と最小荷重の差）と式（3）で定義される変位の変動幅（最大変 位と最小変位の差）の比で定まる等価剛性であるので, 摩擦剛性 $K_{\mathrm{Bf}}$, および, 粘性係数 $C_{\mathrm{Bf}}$ を試験結果から定量 的に決定することができる. その結果を表 3 に示す. 摩擦剛性は, 線形弾性剛性の $0.3 \%$ 程度であり, 上述した仮 定 $K_{\mathrm{Se}} \gg K_{\mathrm{Sf}}$ と矛盾しない.

Table 3 model parameters $K_{\mathrm{Bf}}, C_{\mathrm{Bf}}$ and stiffness $K_{\mathrm{Be}}$ in equation (12).

\begin{tabular}{ll|cr}
\hline \hline Friction Stiffness & $K_{\mathrm{Bf}}$ & $7.253 \times 10^{-3}$ & {$[\mathrm{kN} / \mathrm{mm}]$} \\
\hline Friction Viscosity & $C_{\mathrm{Bf}}$ & $2.476 \times 10^{-3}$ & {$[\mathrm{kNsec} / \mathrm{mm}]$} \\
\hline Specimen Stiffness & $K_{\mathrm{Be}}$ & 2.225 & {$[\mathrm{kN} / \mathrm{mm}]$} \\
\hline
\end{tabular}

\section{2 摩擦ヒステリシスのカ学モデル}

3.2，3·3, および，4.1 節では, 摩擦損失エネルギによってヒステリシスを評価するが，ここで，摩擦損失エネ ルギと最大荷重時において試験体内に導入されるひずみエネルギとの比を用いて, ヒステリシスを議論する. 最 大荷重時に試験体 B に導入されるひずみエネルギ $W_{\mathrm{B}}$ は, 荷重の変位に対する非線形性を無視すると,

$$
W_{\mathrm{B}}=\int_{0}^{\delta_{\max }} F \mathrm{~d} \delta=\frac{P^{2}}{2 K_{\mathrm{Be}}}
$$

である，あらためて，式（12）の式（13）に対する比を試験体 B の摩擦ヒステリシス $H_{\mathrm{Bf}}$ として定義すると， 


$$
\begin{aligned}
& H_{\mathrm{Bf}} \equiv \frac{E_{\mathrm{Bf}}}{W_{\mathrm{B}}} \\
& \simeq \frac{2 K_{\mathrm{Bf}}}{K_{\mathrm{Be}}}+\frac{4 C_{\mathrm{Bf}} v}{P}
\end{aligned}
$$

と表せ，右辺第一項は，摩擦剛性と線型弾性剛性の比を 2 倍した最大荷重にも速度にも依存しない静的摩擦ヒス テリシス, 第二項は, 粘性抵抗と最大荷重の比を 4 倍した值である動的摩擦ヒステリシスとして理解できる. 表 3 に示す值を用いると, 静的摩擦ヒステリシスは約 $0.6 \%$ と求まる. 速度に比例して動的摩擦ヒステリシスが全体に 占める割合が高くなるが，式（12）で定義される摩擦損失エネルギが変位-荷重空間において各辺が変位または荷 重軸に平行で最小荷重点と最大荷重点を対角線とする矩形領域の面積 $P \delta_{\max }=P^{2} / K_{\mathrm{Be}}$ を超えることは物理的にあ り得ないので, 摩擦ヒステリスが2 $(200 \%)$ を超えることはない. したがって, 式 (12) や（14）は, $v \ll P / C_{\mathrm{Bf}}$ の領域でのみ適用可能と考えるべきである.しかし，変形速度が高まることで摩擦ヒステリシスが増加すること が予想され，低荷重で高速変形する状態，例えば，固有振動するケースでは，摩擦が振動減衰の要因になること が予想される.

\section{5. 結言}

プレス成形された鋼板をスポット溶接によって組み立てたダブルハット部品を対象に，準静的，かつ，弾性の 範囲において変形させたときの変位-荷重線図によって囲まれる面積を損失エネルギとし, 溶接フランジ同士がほ ぼ接触していない試験体と強く接触する試験体の損失エネルギの差を算出することで, 測定上不可避的な試験機 における損失を取り除き，溶接フランジにおける接触摩擦を起因とする損失エネルギ（摩擦損失エネルギ）を実 験的に計測する手法を開発した。実験の結果，摩擦損失エネルギは様々な試験条件において非負であり，塑性を伴 わない弾性変形領域であっても摩擦によってヒステリシスが発生することが判明し, 自動車の走行試験における ドライバ官能評価である「剛性感」に影響を及ぼすと言われる車体ヒステリシスの発生要因の一つが車体を構成 する部品間の摩擦である可能性を見出した。

溶接フランジに接触摩擦を有するダブルハット試験体の摩擦損失エネルギは, 最大荷重および荷重速度の増加 に伴い増加し, また, 摩擦損失エネルギの荷重速度依存性である動的特性は最大荷重に比例し, 速度ゼロへの外挿 点である静的特性は最大荷重の平方に比例する. さらに, 試験体中の摩擦による反力を変位の絶対值に比例する Coulomb 摩擦と変位速度に比例する粘性摩擦の和とした力学モデルから予想される試験体の摩擦損失エネルギの 静的および動的特性の最大荷重依存性は, 試験結果と良い一致を示す. 実験結果との比較から, Coulomb 摩擦に おける変位の絶対值の比例係数である摩擦剛性と粘性摩擦における粘性係数が同定される．また，力学モデルか ら, 摩擦損失エネルギと試験体の最大ひずみエネルギとの比として定義する摩擦ヒステリシスは, 速度と荷重に 依存しない静的ヒステリシス，および，速度に比例し最大荷重に反比例する動的ヒステリシスの和になる. 同定 される摩擦剛性を用いると, 静的ヒステリシスは $0.6 \%$ ある. 入力荷重が低く変位速度が高い自動車車体の固有 振動モード（数 $10 \mathrm{~Hz}$ 以上）では, 摩擦ヒステリシスの効果, すなわち, 摩擦減衰が無視できない可能性がある.

今後, 実走行時における車体にかかる荷重や振動が今回の試験形態においてどの程度の荷重および速度域に相 当するのか，および，車体を構成する部品の溶接フランジの接触状態がどのような形態をなしているのかを明確 にし, 実際の自動車車体における静的ヒステリシスや振動減衰に対する溶接フランジ摩擦の影響度を定量的に見 積もることで, ドライバの官能評価である「剛性感」の改善指標を見出すことが期待できる.

\section{文献}

Abad, J., Franco, J. M., Celorrio, R. and Lezáun, L.,Design of experiments and energy disipation analyasis for a contact mechanics 3D model of frictional bolted lap joints, Advances in Engineering Software, No. 45 (2012), pp. 42-53.

Abbadi, Z., Aubby, D., Germes, S., Jezequel, L. and Herpe, F. V., An imploved model for dissipation in welding spot joints, Proceedings of ISMA 2004 (2004), pp. 1207-1220. 
古巣克也，尼子龍幸，中川稔章，浜辺勉，青木典久，エネルギー法による箱型断面梁の曲げ座屈, 日本機械学会論 文集, Vol. 81, No. 828 (2015), DOI: 10.1299/transjsme.15-00115.

平居嵩朗，鞍谷文保，小出一志，城戸一郎，部分的な重なりを有する平板接合構造の簡易減衰推定法，日本機械 学会論文集, Vol. 80, No. 812 (2014), DOI: 10.1299/transjsme.2014trans0075.

Irwin, I. W., Perception, comfort and performance criteria for human beings exposed to whole body pure yaw vibration and vibration containing yaw and translational components, Journal of Sound and Vibration, Vol. 76, No. 4 (1981), pp. 481-497.

中谷弘能, 自動車の望ましい応答特性について - 四輪操舵車を用いた操安性の研究 -, 国際交通安全学会誌, Vol. 10, No. 2 (1984), pp. 146-154.

椎葉太一, 小池亮太, 陳思予, フレキシブルマルチボディ車両モデルを用いたレーシングカートの運動特性評価, 日本機械学会論文集 C 編, Vol. 79, No. 806 (2013), pp. 3291-3303.

嶋中常規, 中山伸之, 友貞賢二, 吉井群冶, 渡邊雅哉, 新型マツダアクセラのダイナミック性能, マツダ技報, No. 27 (2009), pp. 60-65.

品川幹, 社本英二, 機械構造の結合部における摩擦減衰の解明と定量的予測（ねじり振動が作用する場合）, 日本 機械学会論文集 C 編，Vol. 78，No. 790 (2012), pp. 2048-2063.

須藤正俊, 野村伸吾, 溝口孝遠, 田中福輝, 高強度薄鋼板のスポット溶接性, 鉄と鋼, Vol. 68, No. 9 (1982), pp. 1411-1420.

武田健二, 白松広大, 岩田成樹, 寺口毅, 悪路走行入力における車体スポットの疲労強度分析技術の開発, 自動 車技術会学術講演会前刷集, No. 129-13 (2013), pp. 1-7.

武井一剛, 安田栄一, 土居俊一, 前田節雄, 車両のヨー回転振動に対する人間の知覚感度, R\&D Review of Toyota CRDL, Vol. 36, No. 3 (2001), pp. 47-53.

冨岡敏憲，執行貴彦，望月浩孝，CX-9 の車体剛性の開発，マツダ技報，No. 25 (2007), pp. 61-64.

内山翔太, 瀬戸雅宏, 山部昌, ソーラーカーにおけるフレーム剛性が操縦安定性に及ぼす影響, 日本機械学会 第 24 回交通・物流部門大会 講演論文集 No. 15-63 (2015).

吉田裕一, 瀬戸厚司, 磯貝栄志, 潮田浩作, Bestien Weber, スプリングバックの影響を考慮したスポット溶接箱 型断面部材の疲労寿命評価，塑性と加工，Vol. 621, No. 53 (2012), pp. 919-923.

\section{References}

Abad, J., Franco, J. M., Celorrio, R. and Lezáun, L., Design of experiments and energy disipation analyasis for a contact mechanics 3D model of frictional bolted lap joints, Advances in Engineering Software, No. 45 (2012), pp. 42-53.

Abbadi, Z., Aubby, D., Germes, S., Jezequel, L. and Herpe, F. V., An imploved model for dissipation in welding spot joints, Proceedings of ISMA 2004 (2004), pp. 1207-1220.

Furusu, K., Amago, T., Nakagawa, T., Hamabe, T. and Aoki, N., Bending buckling of box beam by energy method, Transactions of the JSME (in Japanese), Vol. 81, No. 828 (2015), DOI: 10.1299/transjsme.15-00115.

Hirai, T., Kuratani, F., Koide, K. and Kido, I., A simplified method for estimating damping of joined plate structures with partial overlap resion, Transactions of the JSME (in Japanese), Vol. 80, No. 812 (2014), DOI: 10.1299/transjsme.2014trans0075.

Irwin, I. W., Perception, comfort and performance criteria for human beings exposed to whole body pure yaw vibration and vibration containing yaw and translational components, Journal of Sound and Vibration, Vol. 76, No. 4 (1981), pp. 481-497.

Nakatani, H., On desirable response characteristics of vehicle - vehicle control studies with 4 wheel steering vehicle -, International Association of Traffic and Safety Sciences, Vol. 10, No. 2 (1984), pp. 146-154 (in Japanese).

Shiiba, T., Koike, R. and Chen, S., Evaluations of racing kart behavior with flexible multibody dynamics, Transactions of the Japan Society of Mechanical Engineers, Series C, Vol. 79, No. 806 (2013), pp. 3291-3303 (in Japanese).

Shimanaka, T., Nakayama, N., Tomosada, K., Yoshii, G. and Watanabe, M., Dynamic performance of all-new Mazda Axela, Mazda technical review, No. 27 (2009), pp.60-65 (in Japanese). 
Shinagawa, M. and Shamoto, E., Clarification and quantitative prediction of friction damping on contact surface of mechanical structure (case of torsional vibration), Transactions of the Japan Society of Mechanical Engineers, Series C, Vol. 78, No. 790 (2012), pp. 2048-2063 (in Japanese).

Sudo, M., Nomura, S., Mizoguchi, T. and Tanaka, Y., Spot weldability of high strength steel sheets, Journal of the Iron and Steel Institute of Japan, Vol. 68, No. 9 (1982), pp. 1411-1420 (in Japanese).

Takeda, K., Shiramatsu, K., Iwata, S. and Teraguchi, T., Development of analytical methods for the fatigue life strength of spot-welding under road load conditions, Proceedings of JSAE Congress, No. 129-13 (2013), pp. 1-7 (in Japanese).

Takei, K., Yasuda, E., Doi, S. and Maeda, S., Human sensitivity for vehicle yaw-motion, R\&D Review of Toyota CRDL, Vol. 36, No. 3 (2001), pp. 47-53 (in Japanese).

Tomioka, T., Shigyou, T. and Mochizuki, H., Body rigidity for CX-9, Mazda technical review, No. 25 (2007), pp. 61-64 (in Japanese).

Uchiyama, S., Seto, M. and Yamabe, M., Influence of frame stiffness on handling stability in solar vehicle, TRANSLOG2015, No. 15-63 (2015) (in Japanese).

Yoshida, Y., Seto, Isogai, E., Ushioda, K. and Weber, B., Fatigue life prediction in spot welded rectangular section members uder springback effect, Journal of the Japan Society for Technology of Plasticity, Vol. 621, No. 53 (2012), pp. 919-923 (in Japanese). 